\title{
BMJ Open Determinants of antenatal care use in nine sub-Saharan African countries: a statistical analysis of cross-sectional data from Demographic and Health Surveys
}

\author{
Amanuel Kidane Andegiorgish (D) , , ${ }^{1,2}$ Mohamed Elhoumed (D) , ${ }^{1}$ Qi Qi, ${ }^{1}$ \\ Zhonghai Zhu, ${ }^{1}$ Lingxia Zeng (D) ${ }^{1}$
}

To cite: Andegiorgish AK, Elhoumed M, Qi Q, et al. Determinants of antenatal care use in nine sub-Saharan African countries: a statistical analysis of cross-sectional data from Demographic and Health Surveys. BMJ Open 2022;12:e051675. doi:10.1136/ bmjopen-2021-051675

- Prepublication history for this paper is available online. To view these files, please visit the journal online (http://dx.doi. org/10.1136/bmjopen-2021 051675).

Received 29 March 2021 Accepted 24 January 2022

Check for updates

(C) Author(s) (or their employer(s)) 2022. Re-use permitted under CC BY-NC. No commercial re-use. See rights and permissions. Published by BMJ.

${ }^{1}$ Department of Epidemiology and Biostatistics, Xi'an Jiaotong University, Xi'an, Shaanxi, China ${ }^{2}$ Department of Epidemiology and Biostatistics, Asmara College of Health Sciences, Asmara, Eritrea

Correspondence to Professor Lingxia Zeng; tjzlx@mail.xjtu.edu.cn

\section{ABSTRACT}

Objective To explore the factors associated with antenatal care (ANC) visits.

Design A secondary data analysis from cross-sectional studies was conducted.

Setting Sub-Saharan Africa.

Participants 56002 women aged 15-49 years in Ghana (3224), Kenya (10 981), Malawi (9541), Namibia (2286), Rwanda (4416), Senegal (6552), Tanzania (5536), Uganda (7979) and Zambia (5487) were analysed.

Outcomes $4^{+}$ANC visits.

Results Overall, $55.52 \%$ (95\% Cl: $55.11 \%$ to $55.93 \%)$ of women made $4^{+}$ANC visits. The highest $4^{+}$ANC visits were in Ghana (85.6\%) and Namibia (78.9\%), and the lowest were in Senegal (45.3\%) and Rwanda (44.5\%). Young women 15-19 years had the lowest uptake of $4^{+} \mathrm{ANC}$ visits. Multivariable analysis indicated that the odds of $4^{+}$ANC visits were $14 \%$ lower among women from rural areas compared with those living in towns (adjusted OR (AOR) $0.86 ; 95 \% \mathrm{Cl}: 0.81$ to 0.91). This difference was significant in Kenya, Malawi, Senegal and Zambia. However, in Zambia, the odds of $4^{+}$ANC visits were $48 \%$ higher (AOR 1.48; 95\% Cl: 1.2 to 1.82) among women from rural compared with urban areas. Women with higher educational level had more than twofold higher odds of $4^{+}$ANC visits in seven of the nine countries, and was significant in Kenya, Malawi, Rwanda and Zambia. Compared with the poorest household wealth category, odds of $4^{+}$ANC visits increased by $12 \%, 18 \%, 32 \%$ and $41 \%$ for every $20 \%$ variation on the wealth quantile. Women in their first-time pregnancy had higher odds of $4^{+}$ANC visits compared with others across all countries, and women who had access to media at least once a week had a $22 \%$ higher probability of $4^{+} \mathrm{ANC}$ visits than women who had no access to media (AOR $1.22,95 \% \mathrm{Cl}$ : 1.15 to 1.29$)$.

Conclusion The number of ANC visits was considered to be inadequate with substantial variation among the studied countries. Comprehensive interventions on scaling uptake of ANC are needed among the low-performing countries. Particular attention should be given to women of low economic status and from rural areas.
Strengths and limitations of this study

- The analytical approach both as pooled data support the outcome to be valid and the merit in segregating data allows to focus on aspects of antenatal care visits that may remain hidden in intranational/national level indicators.

- The study used national representative samples from nine sub-Saharan African countries which have been linked to enhance the generalisability of the study.

- This analysis included women who had birth 3 years before the survey, which could minimise the recall bias of self-report at a single point in time.

- The cross-sectional nature of the study design cannot affirm the cause-effect or direction of association of the predictors.

Since the data sets were obtained from countries Demographic and Health Surveys in a different time, awareness of participants may be varied due to time heterogeneity.

\section{INTRODUCTION}

Maternal and neonatal mortality is a significant public health issue that reflects the overall status of a country's healthcare system and socioeconomic development. ${ }^{1}$ The WHO estimates that approximately 830 maternal deaths/day from preventable causes are related to pregnancy and childbirth. Almost all $(99 \%)$ of these deaths occur in lowincome countries. ${ }^{2}$ Sub-Saharan Africa (SSA) remains the region with the highest maternal and under-5 mortality. ${ }^{3-5}$ Almost half of the under- 5 deaths occur among newborn babies whose deaths could be prevented by reaching a high coverage of quality antenatal care (ANC), skilled care at birth, postnatal care for mother and baby, and care of small and sick newborns. ${ }^{34}$ Several review studies on interventions for maternal and newborn babies 
have demonstrated that the provision of adequate ANC brings with it a positive impact on pregnancy outcomes, through early diagnosis and appropriate management. ANC has a $39 \%$ reduced risk of neonatal mortality in subSaharan countries. ${ }^{6-9}$

The WHO advises every pregnant woman with a normal pregnancy in middle/low-income countries to attend at least four ANC visits. ${ }^{1}$ However, many women in lowincome countries particularly in SSA have limited access to health providers. ${ }^{10}$ Several studies have attempted to identify the factors associated with the underutilisation of ANC. ${ }^{11}{ }^{12}$ Age, ${ }^{12-16}$ women's education, 8 12-24 husbands' education, ${ }^{18} 2223$ socioeconomic status, ${ }^{14-23} 25$ women's employment, ${ }^{18}$ birth order, ${ }^{11} 1218$ frequency of listening to the radio/watching $\mathrm{TV} /$ reading newspaper/ magazines, ${ }^{811182324}$ and place of residence ${ }^{121316-19222425}$ are among the factors associated with underutilisation of ANC. The factors attributed to inadequate ANC follow-ups are quite substantial across regions and countries. 1116232627

Meeting Sustainable Development Goals (SDGs) to ensure healthy lives and well-being for all ages by 2030 requires transnational organisations' efforts and the ability to collaborate in partnership. Interestingly, the means of implementing and revitalising capacity development and the information exchange of multinational cooperation have been emphasised in the SDGs. ${ }^{28}$ Despite the available evidence on ANC's key role in reducing maternal and neonatal mortality, millions of women in developing countries do not receive it and there remains a high variability $(32 \%-91 \%)$ of four or more ANC $\left(4^{+} \mathrm{ANC}\right)$ visits between countries. ${ }^{21222429}$ Lessons on coverage of crucial ANC visits from neighbouring areas would aid in precise allocations of resources and interventions where they are most needed. Therefore, new research projects on mutual benefit and knowledge sharing at every level must be implemented to attain global health development goals.

We conducted secondary data analysis using the latest (2010-2019) Standard Demographic Health Surveys conducted in nine SSA countries (Ghana, Kenya, Malawi, Namibia, Senegal, Rwanda, Tanzania, Uganda and Zambia). The objective of the study was to understand the factors associated with $4^{+} \mathrm{ANC}$ attendance.

\section{MATERIALS AND METHODS \\ Study design}

We used data from the Demographic and Health Survey (DHS). DHS is a 5-year periodical national representative cross-sectional study using a stratified two-stage cluster sampling design. Details of the DHS protocol are published elsewhere. ${ }^{30}$ Information from ever-married women aged 15-49 years in nine SSA countries on demographic characteristics and reproductive history was collected.

\section{Data sources/measurements}

Data sets were collected through household interviews using a structured questionnaire. Women were interviewed about the number of ANC visits. Trained interviewers obtained informed consent from all eligible women in selected households before conducting the interview using pencil and paper questionnaires. The surveys are weighted for oversampling or undersampling and non-response. Thus, the design and standardised core modules allow for regional and transnational comparison of the data. Field supervisors and data clerks checked all forms before entering them into databases. Data for this analysis were taken from the latest household survey of the studied countries. This study's survey years ranged from 2010 to 2019, and the sample size ranges from 2286 in Namibia to 10981 in Kenya.

Countries were selected based on the availability of recent standard DHS data after 2010 and representing the four different subregions of SSA, that is, Western, Central, Southern and Eastern Africa. The nine countries included in this analysis and their year of survey are: Ghana (DHS 2014), Kenya (DHS 2014) Malawi (DHS 2015/2016), Namibia (DHS 2013), Rwanda (DHS 2014/2015), Senegal (DHS 2010/2011), Tanzania (DHS 2015/2016), Uganda (DHS 2016) and Zambia (DHS 2018/2019).

\section{Participants}

Women who had one or more births 3 years before the survey were included as study participants. Selection criteria of study participants were shown in figure 1 . In the DHS, information about ANC is only collected for the youngest child under-5years. Therefore, to minimise the degree of error due to recall bias (because in some countries information about ANC visits is subjective from the mother while others check an ANC card), we have limited our analysis to those births that occurred 3 years before the survey. The contribution of study participants is presented in figure 1 .

\section{Exclusion criteria}

ANC provided by non-health professionals such as traditional birth attendants was excluded from the present analysis.

\section{Outcome variable}

We used ANC visits as our primary outcome. We categorised this variable into a binary variable as $4^{+} \mathrm{ANC}$ visits 'yes'=if the mother had at least four ANC visits and 'no'=if the mother had less than four ANC visits during her last pregnancy.

\section{Explanatory variables}

A set of sociodemographic variables related to the utilisation of ANC such as women's age in years, women's and husbands' education and occupation, birth order (parity), frequency of listening to radio/watching TV/ reading magazines, household wealth quantile and place 


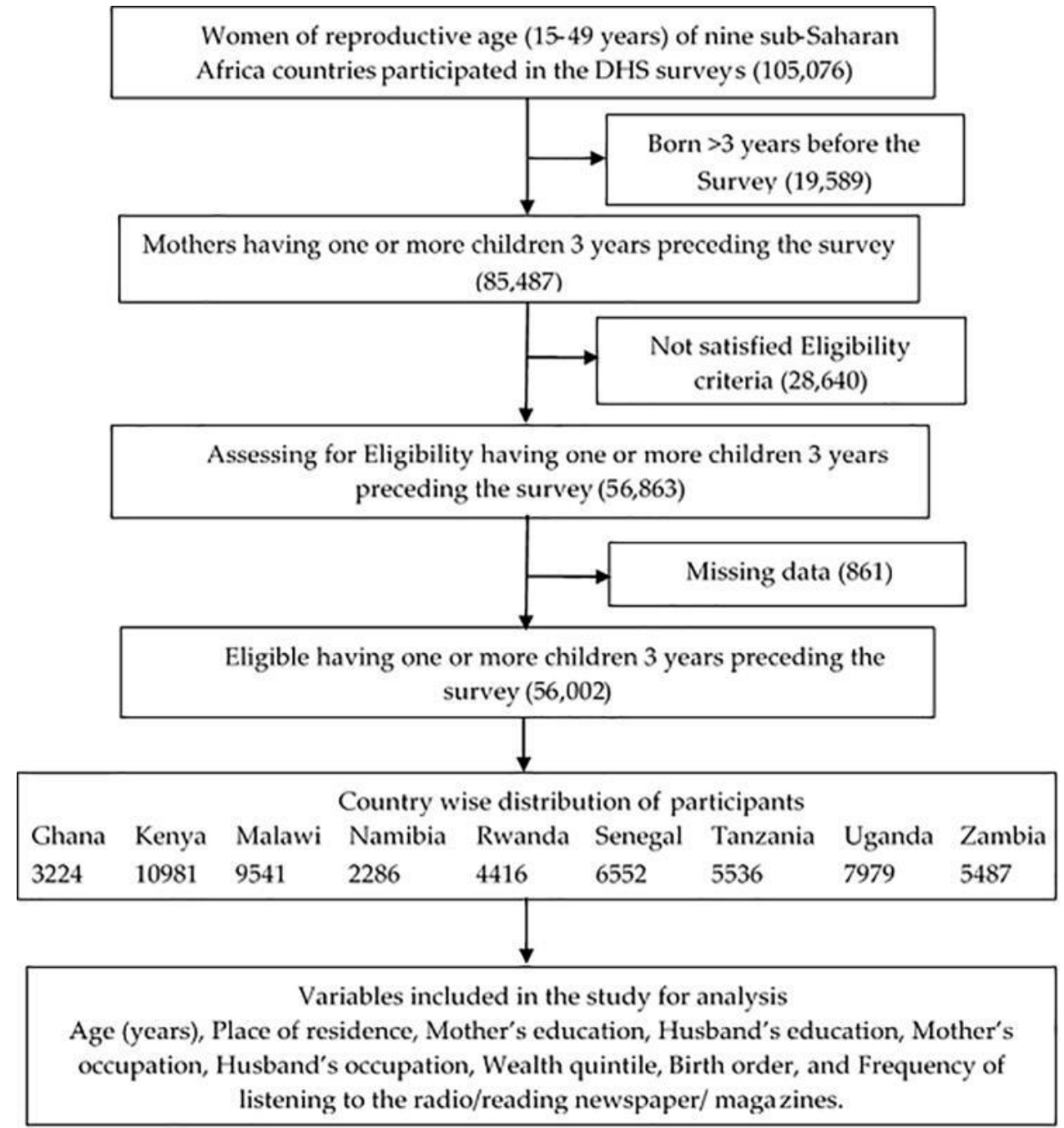

Figure 1 Flow chart of the process of selection of women for analysis of $4^{+}$ANC visits. $4^{+}$ANC, four or more antenatal care; DHS, Demographic and Health Survey.

of residence were identified from the survey data as predictors of ANC follow-ups.

We adapted Anderson's behavioural model framework on factors associated with utilisation of medical care service in developing countries which has been applied in similar studies. ${ }^{17}$ Variables with missing values $(>10 \%)$ on enabling and need factors were excluded from the analysis due to limited representativeness.

Numerical values like age, ANC visits and years of education attended were grouped into categories. Women's age in years was tabulated into groups (15-19years, 20-24 years, 25-29years, 30-34 years, 35 and above); women's and husbands' education were classified as 'no schooling', 'primary', 'secondary' and 'higher' education. Women's and husband's occupation were classified as 'not working outside home', 'professional/ skilled work', 'agriculture' and 'unskilled'. Frequency of listening to radio/watching TV/reading magazines (not at all, less than once a week and at least once a week) was included to gauge the women's exposure to promotion messages on the benefits of ANC attendance. The household wealth index was constructed using principal component analysis from items related to possession of durable assets, access to utilities and infrastructure, and housing characteristics. Each woman was ranked into five categories (poorest, poorer, middle, richer and richest) based on a household asset score, comprising $20 \%$ of the population. ${ }^{11}{ }^{31}$ Place of residence/ecological status identified from the survey assessed the difference in the availability and accessibility of services among urban and rural areas and were used as predictors of ANC follow-up.

\section{Data analysis}

Data analysis was performed using STATA software V.14.0. Descriptive analysis was conducted on combined and separate forms for the studied country. $\mathrm{X}^{2}$ tests were used to analyse the potential factors affecting ANC use during a woman's last pregnancy 3 years before the survey. Bivariate and multivariable regression analyses were used to study the statistical association between the explanatory variables and $4^{+}$ANC. A multilevel analysis was used in which the level of coefficients was modelled as a function of predictors considering the average log odds of $4^{+} \mathrm{ANC}$ across the studied countries. Women's age at childbirth 
and husband's occupation were excluded from the multilevel analysis due to collinearity effects with a variance inflation factor value $(>4)$ on the collinearity diagnosis test. A two-sided $p$ value of $<0.05$ was considered statistically significant in this study.

\section{Patient and public involvement}

The study used publicly available secondary data from the DHS (https://dhsprogram.com/). Patients and the public were not involved in the design and conduct of this research.

\section{RESULTS}

\section{Baseline characteristics of the study population}

A total of 56002 women with complete details from nine SSA countries were available. The distribution of study participants is presented in figure 1. Sixty-one per cent of the female participants were less than 30 years old and about three-fourths $(73.2 \%)$ of the total were from rural places of residence. Rates of illiteracy in the studied countries were high. More than one-fifth $(22.5 \%)$ of all women or their husbands had no schooling. More women $(51.2 \%)$ had a primary level of education than their husbands (44.8\%); while women's unemployment status (no working outside home) was higher than their husband's $(31.5 \%$ vs $4.2 \%)$. More than a quarter $(27.3 \%)$ of all households were in the lowest (poorest) wealth quantile and $24 \%$ of the women were having their first child (primigravidae) (table 1).

Overall, $55.52 \%$ (95\% CI: $55.11 \%$ to $55.93 \%$ ) of the women had at least four ANC visits with a skilled health provider during pregnancy. Thirty-five per cent of the women started their first ANC visit in the first trimester and $57 \%$ in the second trimester of pregnancy. Before pregnancy, $82.2 \%$ of women in this study had received a tetanus injection. There were 1808 deaths (32.3 deaths/1000 live births) among newborns in the 3 years preceding the survey.

The highest proportion of $4^{+}$ANC visits among the studied countries was from Ghana $(85.61 \%)$, followed by Namibia (78.92\%) and Zambia (64.2\%), and the lowest proportion was from Rwanda (44.5\%), Senegal (45.3\%) and Tanzania $(48.1 \%)$ (figure 2).

Pooled data (figure 3) illustrate that the highest proportion $(57.3 \%)$ of $4^{+} \mathrm{ANC}$ visits was among women aged 25-29 years old. Women from an urban place of residence accounted for $64.3 \%$ of $4^{+} \mathrm{ANC}$ visits. There was an increased proportion of $4^{+} \mathrm{ANC}$ visits with an increase in women's educational level, husbands' educational level, household wealth status, and access to radio listening/ watching $\mathrm{TV} /$ reading newspapers or magazines. The proportion of $4^{+} \mathrm{ANC}$ visits decreased with an increase in birth order. There was no clear pattern in the association of $4^{+} \mathrm{ANC}$ visits on women's and husbands' occupation levels, although professionals in both groups were higher.

\section{Determinants of $4^{+}$ANC visits}

Table 1 indicates that women aged 25-29 years attended more ANC across all the studied countries $(\mathrm{p}<0.005)$, except in Zambia $(\mathrm{p}=0.361)$. Similarly, women from an urban place of residence had a higher number of ANC visits than women from rural areas $(p<0.001)$, except in Rwanda ( $\mathrm{p}=0.788)$. In Zambia, women from rural areas had higher $4^{+} A N C$ visits $(p<0.001)$. Table 1 shows that women's and husbands' educational level significantly $(p<0.001)$ increased women utilisation of ANC across all the studied countries. The highest $4^{+} \mathrm{ANC}$ attendance was among women and husbands with highest educational level in Ghana, (99.2\% and 96.4\%, respectively), and the lowest was among women of no schooling in Rwanda $(37.6 \%)$ and Tanzania $(38.6 \%)$, and women whose husbands with no schooling in Tanzania (36.3\%).

Occupational status of women and their husbands was associated $(\mathrm{p}<0.001)$ with women's $4^{+}$ANC attendance across all countries except in Rwanda $(\mathrm{p}=0.493)$ and Zambia ( $\mathrm{p}=0.062$ ) where the husband's occupation had no association with women's $4^{+} \mathrm{ANC}$ visits.

Household wealth status (wealth quantile) was significantly associated with $4^{+}$ANC visits $(\mathrm{p}<0.001)$. As the household wealth status increased, the usage of $4^{+} \mathrm{ANC}$ visits increased across all countries except in Rwanda $(p=0.234)$. With the exception of Malawi $(p=0.383)$, most primigravidae women undertook more ANC visits than multiparous women $(\mathrm{p}<0.001)$.

More than one in four $(27.54 \%)$ of the female participants had no access to radio/TV/newspapers or magazines, while $53 \%$ had access to these media at least once a week. Increasing access to media was significantly associated with $4^{+}$ANC attendance $(p<0.001)$, although in Rwanda and Zambia the association was not significant ( $\mathrm{p}=0.147$ and $\mathrm{p}=0.264$, respectively).

\section{Univariate analysis magnitude (ORs and $95 \% \mathrm{CI}$ ) of sociodemographic characteristics for $4^{+}$ANC visits}

Table 2 presents the results of univariate analysis of $4^{+} \mathrm{ANC}$ visits by sociodemographic characteristics across the nine countries in SSA. As shown in table 2, adequate ANC visits were lower among young women (15-19 years) in seven of the nine countries. The difference was significant in Ghana, Kenya, Malawi, Senegal and Namibia. The odds of $4^{+} \mathrm{ANC}$ visits were lower by $2 \%-60 \%$ among rural residents compared with urban residents across all countries $(p<0.001)$ except in Zambia, in which women from rural places were $26 \%$ more likely to attend $4^{+} \mathrm{ANC}$ visits. The difference was significant in all countries except Rwanda $(\mathrm{p}=0.283)$.

Four or more ANC visits had a positive association with increasing educational level. Women and husbands with secondary and higher education had significantly higher odds of $4^{+}$ANC visits across all the studied countries $(\mathrm{p}<0.05)$.

Compared with women who did not work outside home, the odds of $4^{+} \mathrm{ANC}$ visits were significantly higher among professional women. Odds of $4^{+} \mathrm{ANC}$ visits in relation to household wealth status showed considerable variation among the countries ranging from 1.10 (95\% CI: 


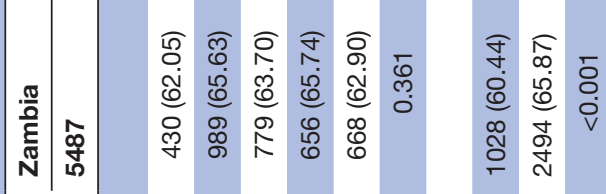

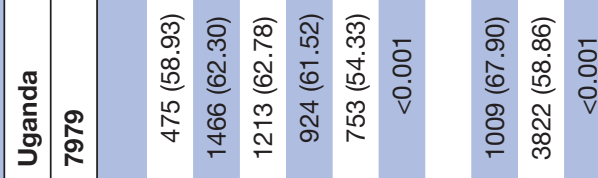

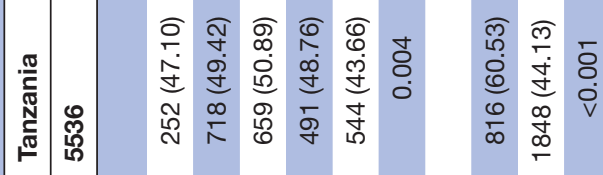

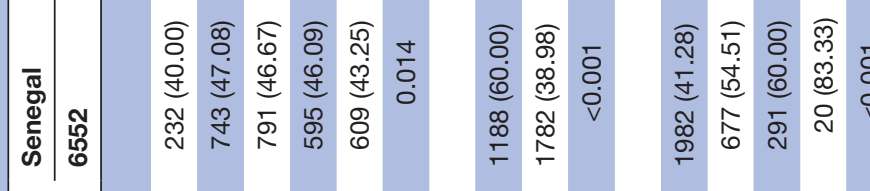

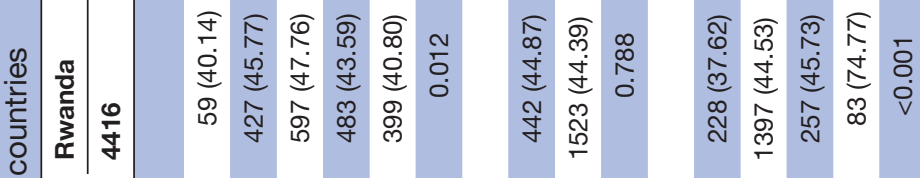

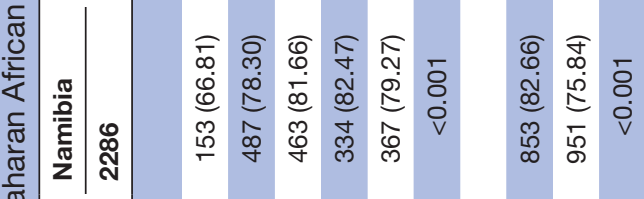

กั

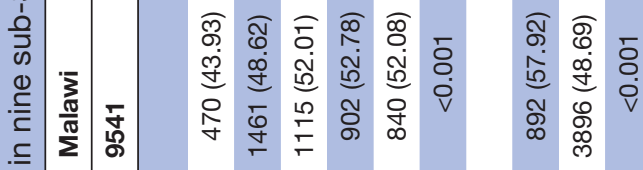

$\frac{0}{\frac{5}{5}}$

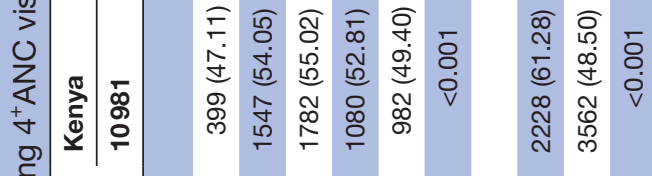

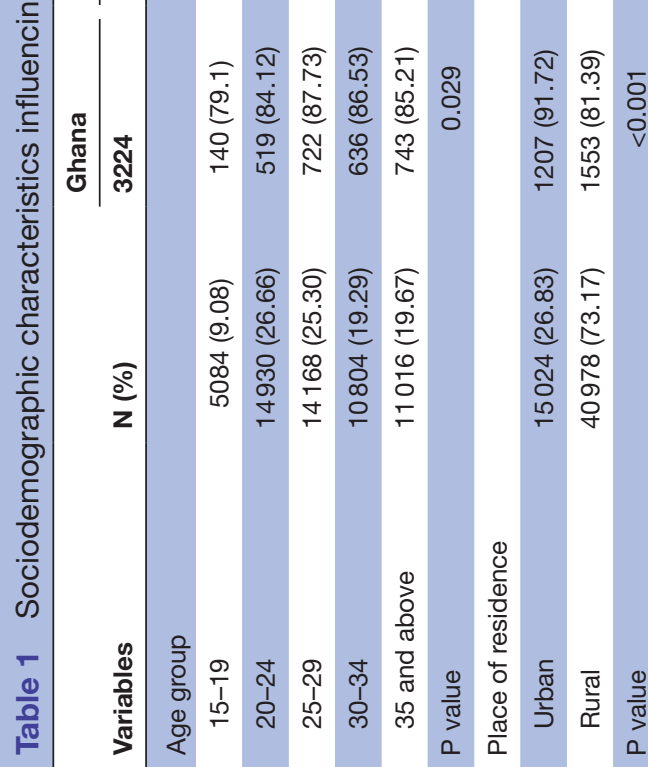

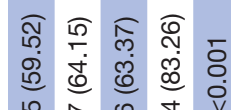

峁

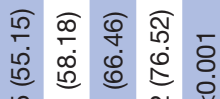

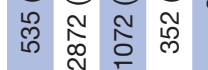

สิธ $\bar{\emptyset}$

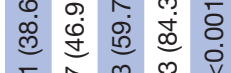

ฟัง

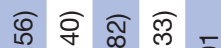

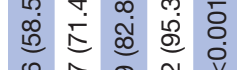

은 유원

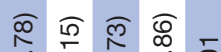

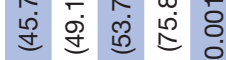

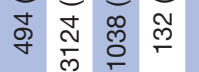

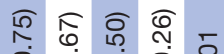

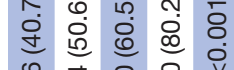

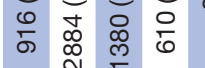

ลิ ชิ

வ

范

ণั จุ

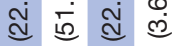

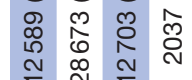

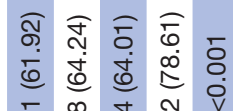

ঢ

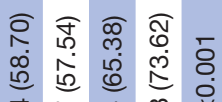

壵 莡吉

今 छ ब

की

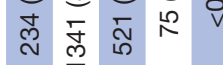

ธู बิ

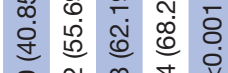

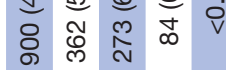

तิ ષิ लำ

守守过

永

ळ

先

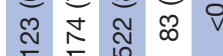

โิ

过过

峁染

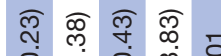

过造 远

苞点余岂

땅ㅎํ ब

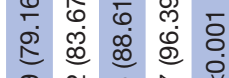

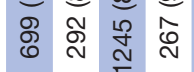

लำ $\widehat{\infty}$

瓷过这

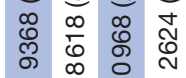

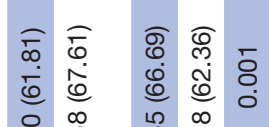

:

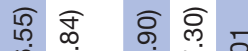

迎过 造

운

突

สু $\bar{\sigma}$ ळ

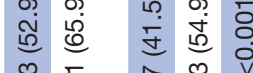

जै 원

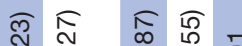

疍

苋

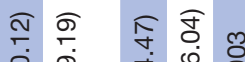

过 守

일

过

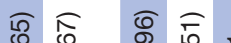

点

要

ळ

व

乎

这 造

草

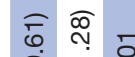

守 通

लू

oิ

这

กั

官

กิ

유

हु बृ

点

ब

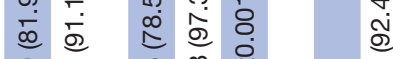

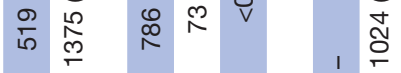

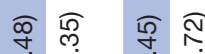

ले

సิ สิ

ले กิ

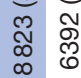

ล ส

过岗

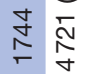

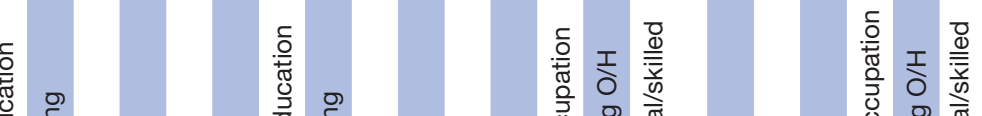

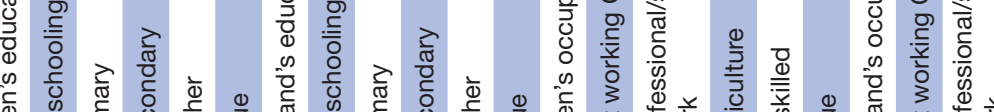

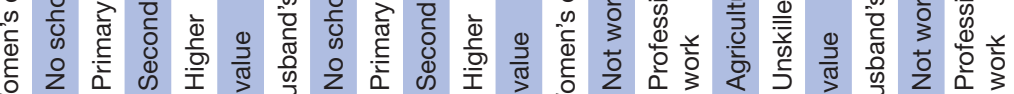

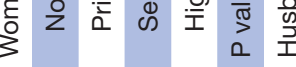
오 고

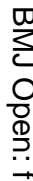

$\stackrel{\vec{B}}{\stackrel{9}{g}}$

$\frac{\bar{c}}{\frac{0}{5}}$

$\stackrel{10}{2}$

음

$\overrightarrow{\vec{\omega}}$

을.

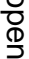

กิ

俩

을 


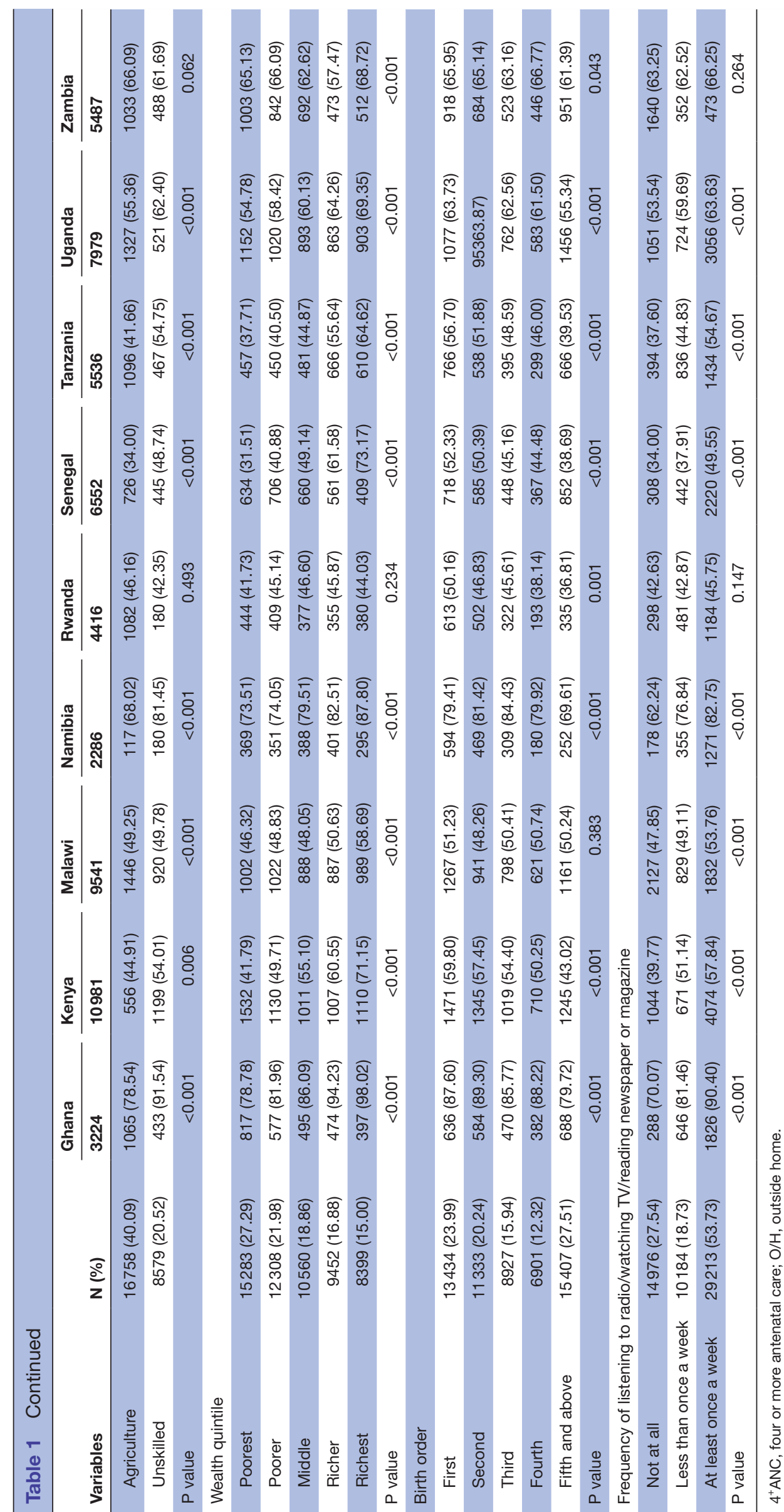




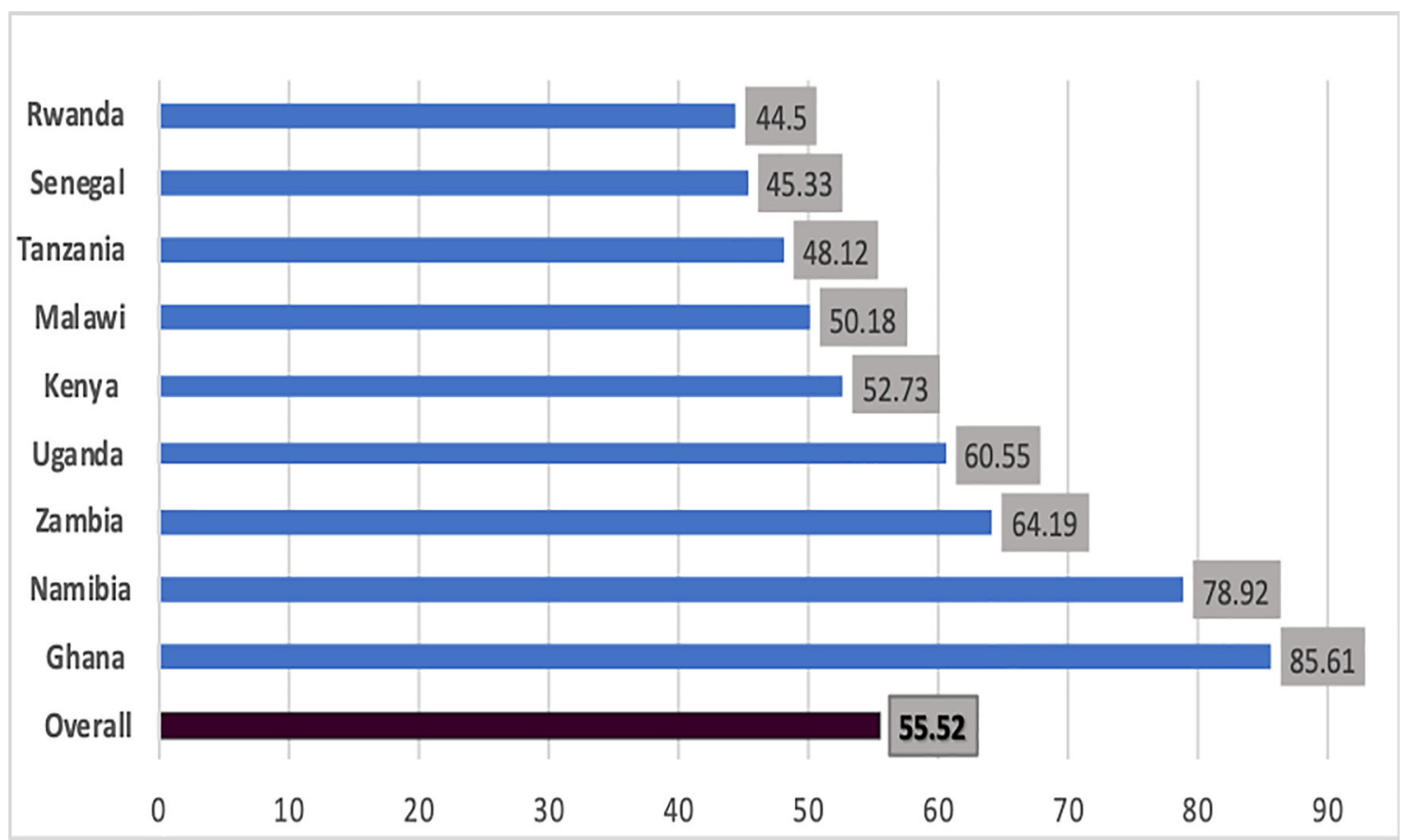

Figure 2 Proportion of $4^{+} \mathrm{ANC}$ visits of women in nine sub-Saharan African countries, 3years preceding the DHS of each country. $4^{+} \mathrm{ANC}$, four or more antenatal care; DHS, Demographic and Health Survey.

0.92 to 1.32 ) in Rwanda to 13.36 (95\% CI: 6.53 to 27.33 ) in Ghana.

The pattern of $4^{+} \mathrm{ANC}$ utilisation showed an inverse relationship with birth order. Women of fifth and above birth order had significantly lower ANC attendance than first birth order. Listening to radio/watching TV/reading newspapers or magazines had a significant positive association with $4^{+} \mathrm{ANC}$ attendance across all countries except in Rwanda and Zambia (table 2).

\section{Multivariable findings}

Table 3 summarises data analysis results adjusted by sociodemographic variables and adjusted by country.

Overall, the likelihood of $4^{+} \mathrm{ANC}$ visits was $14 \%$ lower among women from rural areas than from towns (adjusted OR (AOR) 0.86; 95\% CI: 0.81 to 0.91 ). Multivariable logistic regression analysis exploring the relationship between $4^{+} \mathrm{ANC}$ visits and place of residence was significant in four countries (Kenya, Malawi, Senegal and Zambia). While in Ghana, Namibia, Rwanda, Tanzania and Uganda, $4^{+} \mathrm{ANC}$ visits had no association with place of residence. In Zambia, the odds of $4^{+}$ANC visits were $48 \%$ higher (AOR 1.48; 95\% CI: 1.2 to 1.82 ) among women from rural than urban areas.

Findings of selected sociodemographic predictors related to ANC visit after adjustment for country variations indicated that the odds of $4^{+} \mathrm{ANC}$ visits increased from 14\% (AOR 1.14, 95\% CI: 1.07 to 1.21, p<0.001) to $96 \%$ (AOR 1.96, 95\% CI: 1.65 to $2.33, \mathrm{p}<0.001$ ) with an increase in women's educational level. Women with higher educational levels had more than twofold higher odds of $4^{+} \mathrm{ANC}$ visits in seven of the nine countries, and the difference was significant in four (Kenya, Malawi,
Rwanda and Zambia). Husband's higher educational level had significant association with $12 \%$ (AOR 1.12, 95\% CI: 1.05 to 1.20 ) to $48 \%$ (AOR $1.48,95 \%$ CI: 1.31 to 1.69$)$ higher odds $4^{+} \mathrm{ANC}$ visits of women $(\mathrm{p}<0.001)$. Association of husband's education and $4^{+} \mathrm{ANC}$ visits of women was significant only in Kenya, Malawi and Zambia.

Overall, women's occupation had a positive association with $4^{+} \mathrm{ANC}$ visits. The variations on $4^{+} \mathrm{ANC}$ visits were $19 \%$ (AOR 1.19, 95\% CI: 1.11 to 1.27 ), $7 \%$ (AOR 1.07, 95\% CI: 1.01 to 1.13 ), and $13 \%$ (AOR $1.13,95 \%$ CI: 1.05 to 1.21) greater among professional/skilled women, those working in agriculture, and unskilled labour, respectively, compared with women not working outside home. In Ghana, the odds of $4^{+} \mathrm{ANC}$ visits were more than 15 times (AOR 15.54, 95\% CI: 2.1 to 114.9) higher among employed women than women who had no work outside the home. Women in Uganda were $62 \%$ more to attend $4^{+} \mathrm{ANC}$ visits (AOR 1.62, 95\% CI: 1.28 to 2.05 ). Agricultureemployed women in Kenya, Senegal and Tanzania, and unskilled workers in Rwanda, Tanzania and Zambia had non-significant lower uptake of $4^{+} \mathrm{ANC}$ visits.

Women in the wealthiest group were highly likely to undertake $4^{+} \mathrm{ANC}$ visits. After adjusting for country, ANC service utilisation increased by $12 \%$ (AOR 1.12, 95\% CI: 1.06 to 1.19 ), $18 \%$ (AOR 1.18, 95\% CI: 1.11 to 1.26 ), $32 \%$ (AOR 1.32, 95\% CI: 1.23 to 1.42 ), and $41 \%$ (AOR 1.41, 95\% CI: 1.29 to 1.55 ) for every $20 \%$ variation on the wealth category compared with the poorest level $(\mathrm{p}<0.001)$ (table 3$)$. This association was uniform across the studied countries except in Rwanda where women in the highest wealth quantile were 23\% lower (AOR $0.77,95 \%$ CI: 0.57 to 1.02 ) to make $4^{+} \mathrm{ANC}$ visits than the 

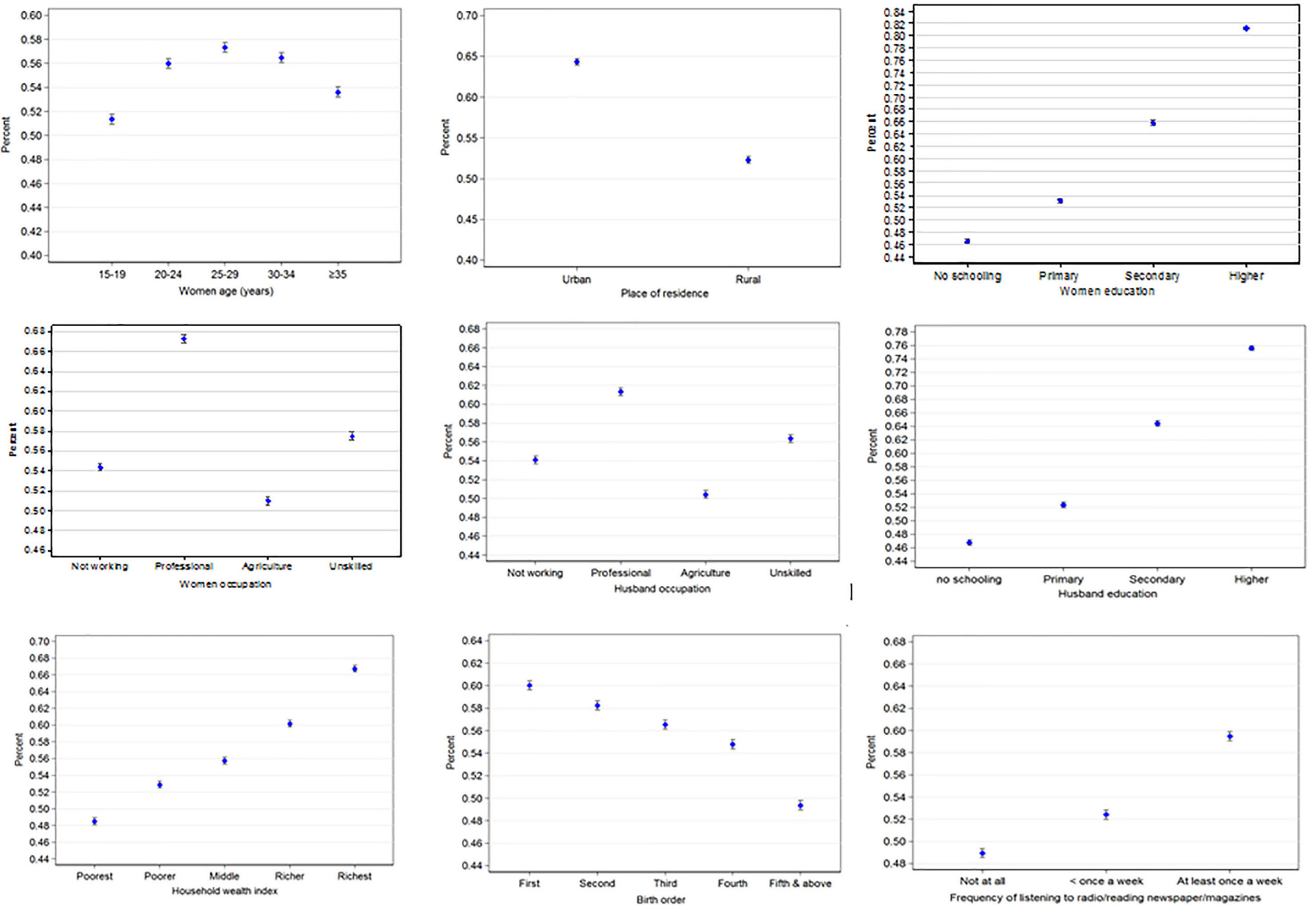

Figure 3 Proportion of $4^{+}$ANC visits of women in nine sub-Saharan African countries and their sociodemographic factors, with $95 \% \mathrm{Cl} .4^{+} \mathrm{ANC}$, four or more antenatal care.

poorest group. The odds of $4^{+} \mathrm{ANC}$ visits were $4 \%$ (AOR $0.96,95 \%$ CI: 0.78 to 1.19 ) and $14 \%$ (AOR $0.86,95 \%$ CI: 0.64 to 1.16 ) lower among middle and richer economic status in Zambia.

Women with previous birth experience had a significant lower uptake of ANC services than first birth order $(p<0.001)$. Odds of $4^{+}$ANC visits were lower by $16 \%$ (AOR 0.84, $95 \%$ CI: 0.79 to 0.90 ), $21 \%$ (AOR $0.79,95 \%$ CI: 0.74 to 0.85 ), $23 \%$ (AOR $0.77,95 \%$ CI: 0.72 to 0.83 ), and $32 \%$ (AOR 0.68, 95\% CI: 0.64 to 0.73 ) for second, third, fourth, and fifth and above birth orders than women who had their first birth (table 3). Birth order difference on $4^{+} \mathrm{ANC}$ visits was significant in Kenya, Rwanda, Senegal, Tanzania, Uganda and Zambia.

Women who had access to media at least once a week had $22 \%$ higher odds of $4^{+} \mathrm{ANC}$ visits than women who had no access (AOR 1.22, 95\% CI: 1.15 to 1.29 ). This association was significant in all countries except in Malawi, Rwanda, Senegal and Zambia.

\section{DISCUSSION}

Every pregnant woman should receive quality care throughout her pregnancy. However, in the nine SSA countries examined in this study, only $55.52 \%$ (95\%
CI: $55.11 \%$ to $55.93 \%$ ) attended $4^{+} \mathrm{ANC}$ visits. There were disparities between the countries in the proportion of women attending $4^{+} \mathrm{ANC}$ visits, with the highest in Ghana $(85.61 \%)$ followed by Namibia $(78.92 \%)$ and Zambia (64.2\%), and the lowest proportion from Rwanda $(44.5 \%)$, Senegal $(45.3 \%)$ and Tanzania $(48.1 \%)$.

Demographic and socioeconomic factors, including place of residence, women's and husbands' educational level, women's and husbands' occupational status, household wealth quantiles, birth order and access to media were significant determinants of $4^{+} \mathrm{ANC}$ attendance. Therefore, there is an urgent need on interventions directed towards maximising the utilisation of ANC in the SSA.

The strength of this analysis is that we used nationally representative data, from nine SSA countries, assumed to have minimum sampling (random or systemic) or instrumental errors through the use of appropriate multistage stratified cluster sampling strategies, having a large sample size of 56002 respondents, and weighted data analysis with reliable test of instrumentations. The analytical approach as pooled data support the outcome to be valid and the merit in segregating data allowed a focus on aspects of ANC visits that may remain hidden 
Table 2 Univariate analysis of sociodemographic factors influencing $4^{+}$ANC visits in nine sub-Saharan African countries

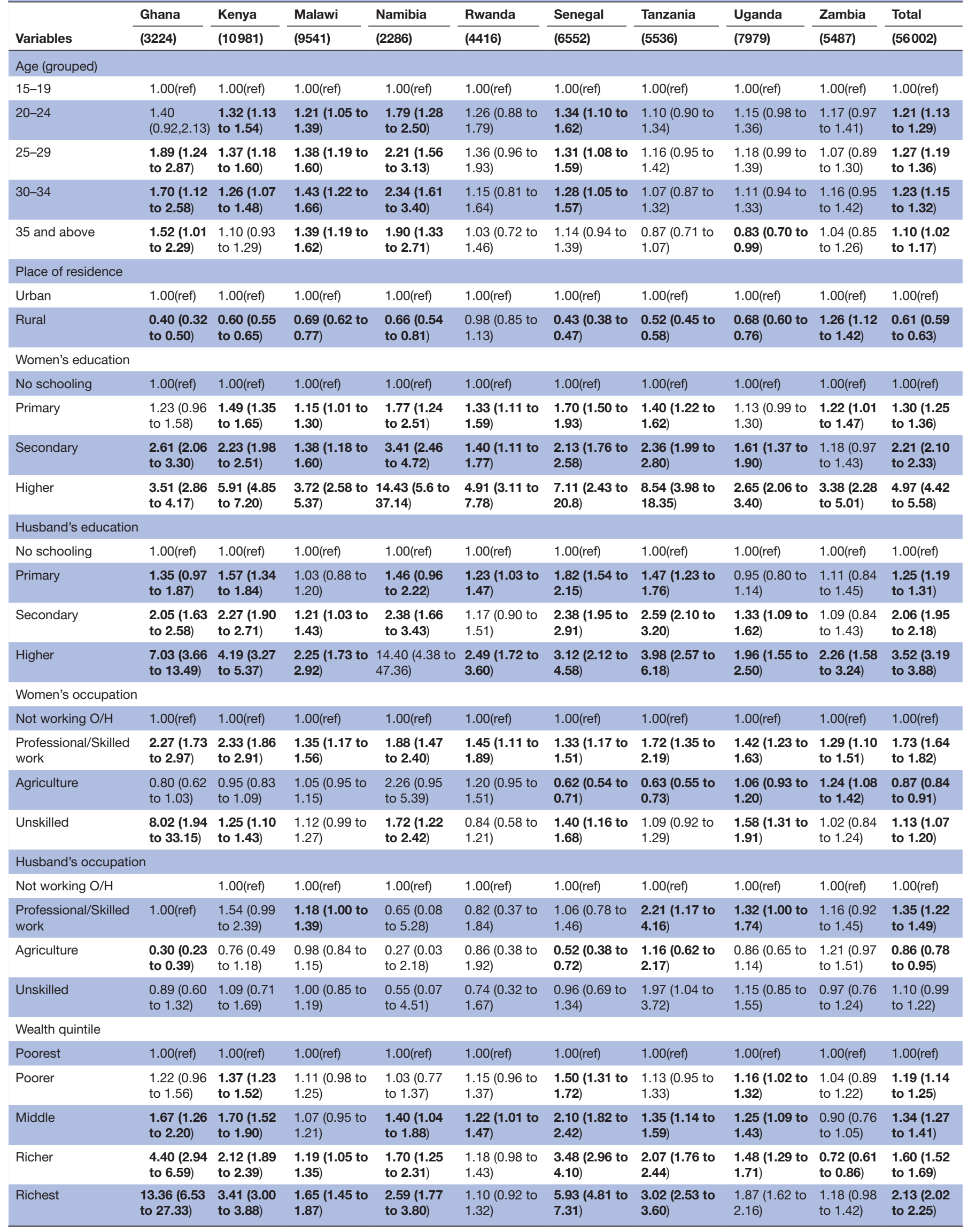


Table 2 Continued

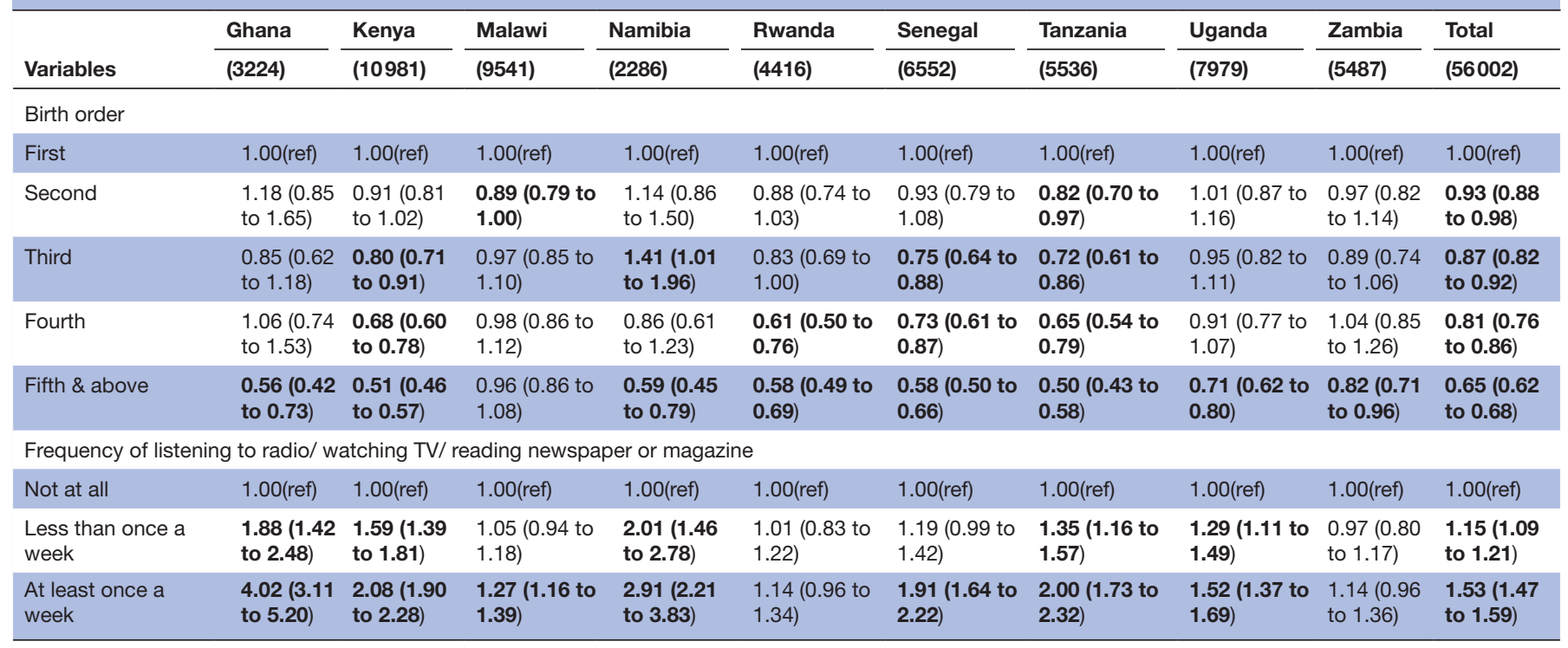

Bold font indicates a significant difference from reference at $\mathrm{p}<0.05$.

$4^{+} \mathrm{ANC}$, four or more antenal care; $\mathrm{O} / \mathrm{H}$, outside home.

in intranational/national level indicators. Recall biases of self-reported data and the cross-sectional nature of the studies limit the cause-effect association of potential predictors. Since the data were obtained from countries' DHS at different times, awareness of participants may differ. Moreover, the data in the present analysis did not consider the quality of care provided to pregnant women during ANC visits which could be a potential predictor for ANC attendance.

Pooled data, adjusted by country, showed that a rural place of residence, no schooling of either the wife or husband, no maternal employment, low household economic status, second and higher birth order, and lack of access to media were significantly associated with lower utilisation of $4^{+} \mathrm{ANC}$ visits (table 3 ). This is in line with previous studies from low/middle-income countries. $^{6} 1115182123$

Country-level data showed that Ghana and Namibia had the highest attendance of $4^{+} \mathrm{ANC}$ visits across all reproductive age groups. The finding from Ghana was in line with the 2013 cross-sectional study where $86 \%$ of Ghanaian women reported attending $4^{+} \mathrm{ANC}$ visits. ${ }^{21}$ Consistent with the finding from other studies, in India and Nigeria, this report also showed that $4^{+} \mathrm{ANC}$ visits were very low in Rwanda, Senegal, Tanzania, Malawi and Kenya. ${ }^{23} 24$

Women from rural areas had 5\%-27\% lower odds of $4^{+} \mathrm{ANC}$ visits in eight of the nine studied countries, and was significant in Kenya, Malawi and Senegal. However, contrary to other studies, there was a $48 \%$ greater uptake of $4^{+} \mathrm{ANC}$ visits by rural residents from Zambia (table 3). ${ }^{22-24}$

Multivariable analysis indicated that higher education among both women and men was a significant predictor of $4^{+}$ANC visits. ${ }^{6} 81118{ }^{23}$ Women with higher educational levels had more than twofold higher odds of $4^{+} \mathrm{ANC}$ visits. This difference was significant in Kenya, Malawi, Rwanda and Zambia. Similarly, having a husband with a higher educational level was significantly associated with $4^{+} \mathrm{ANC}$ visits among women from Kenya, Malawi and Zambia. ${ }^{32}$

Women's occupation had non-uniform association with $4^{+} \mathrm{ANC}$ visits across countries. Women from Ghana and Uganda working as professional/skilled, agriculture and unskilled labour attended more ANC visits than women who did not work outside the home, a finding similar to other studies. ${ }^{18}$ However, this association was not significant in seven of the nine countries (Kenya, Malawi, Namibia, Rwanda, Senegal, Tanzania and Zambia). ${ }^{11}$

Both univariate and multivariable analyses indicated that difference in wealth quantiles was associated with attendance at $4^{+} \mathrm{ANC}$ visits. ${ }^{7821} 25$ Women from the highest wealth category had significantly greater access to $4^{+} \mathrm{ANC}$ visits than those in the lowest category. This was significant in Ghana, Kenya, Malawi, Senegal, Tanzania and Uganda. In Rwanda, women in the richest wealth quantile had $23 \%$ lower (AOR 0.77, 95\% CI: 0.57 to 1.02 ) $4^{+} \mathrm{ANC}$ visits than the poorest group, which is different from the existing literature. ${ }^{11182123}$

Our findings revealed that women in their first pregnancy were more likely to attend $4^{+} \mathrm{ANC}$ visits than second pregnancies and above, except in Namibia. This might be due to them being more careful about pregnancy. ${ }^{33}$ This difference was significant in Kenya, Rwanda, Senegal, Tanzania, Uganda and Zambia, and was similar to previous studies. ${ }^{10} 18$ Consistent with our findings in Namibia, research from Nigeria suggested that adolescents are less likely to attend ANC services. ${ }^{29}$

Listening to radio/watching $\mathrm{TV} /$ reading newspapers or magazines at least once a week was positively associated with the uptake of $4^{+} \mathrm{ANC}$ visits across all the studied 
Table 3 Adjusted multivariable analysis of sociodemographic factors influencing $4^{+} \mathrm{ANC}$ visits in nine sub-Saharan African countries

\begin{tabular}{|c|c|c|c|c|c|c|c|c|c|c|}
\hline Variables & Ghana & Kenya & Malawi & Namibia & Rwanda & Senegal & Tanzania & Uganda & Zambia & Overall * \\
\hline \multicolumn{11}{|l|}{ Place of residence } \\
\hline Urban & 1.00 (ref) & 1.00 (ref) & 1.00 (ref) & 1.00 (ref) & 1.00 (ref) & 1.00 (ref) & 1.00 (ref) & 1.00 (ref) & 1.00 (ref) & 1.00 (ref) \\
\hline Rural & $\begin{array}{l}0.84(0.61 \\
\text { to } 1.15)\end{array}$ & $\begin{array}{l}0.83(0.72 \\
\text { to } 0.90)\end{array}$ & $\begin{array}{l}0.83(0.71 \text { to } \\
0.96)\end{array}$ & $\begin{array}{l}0.83(0.57 \\
\text { to } 1.21)\end{array}$ & $\begin{array}{l}0.95(0.77 \\
\text { to } 1.18)\end{array}$ & $\begin{array}{l}0.73(0.62 \text { to } \\
0.84)\end{array}$ & $\begin{array}{l}0.83 \text { (0.69 to } \\
1.01)\end{array}$ & $\begin{array}{l}0.86(0.72 \text { to } \\
1.01)\end{array}$ & $\begin{array}{l}1.48(1.20 \\
\text { to } 1.82)\end{array}$ & $\begin{array}{l}0.86(0.81 \text { to } \\
0.91)\end{array}$ \\
\hline \multicolumn{11}{|l|}{ Women's education } \\
\hline No schooling & 1.00 (ref) & 1.00 (ref) & 1.00 (ref) & 1.00 (ref) & 1.00 (ref) & 1.00 (ref) & 1.00 (ref) & 1.00 (ref) & 1.00 (ref) & 1.00 (ref) \\
\hline Primary & $\begin{array}{l}1.06 \\
(0.78 .1 .43)\end{array}$ & $\begin{array}{l}1.12(0.90 \\
\text { to } 1.39)\end{array}$ & $\begin{array}{l}1.09 \text { (0.94 to } \\
1.27)\end{array}$ & $\begin{array}{l}1.34(0.83 \\
\text { to } 2.16)\end{array}$ & $\begin{array}{l}1.20(0.99 \\
\text { to } 1.46)\end{array}$ & $\begin{array}{l}1.06 \text { (0.91 to } \\
1.23)\end{array}$ & $\begin{array}{l}1.04 \text { (0.88 to } \\
1.22)\end{array}$ & $\begin{array}{l}1.03 \text { (0.87 to } \\
1.22)\end{array}$ & $\begin{array}{l}1.12(0.90 \\
\text { to } 1.41)\end{array}$ & $\begin{array}{l}1.14(1.07 \text { to } \\
1.21)\end{array}$ \\
\hline Secondary & $\begin{array}{l}1.47(1.05 \\
\text { to } 2.05)\end{array}$ & $\begin{array}{l}1.23(0.94 \\
\text { to } 1.60)\end{array}$ & $\begin{array}{l}1.11(0.91 \text { to } \\
1.35)\end{array}$ & $\begin{array}{l}1.78(1.04 \\
\text { to } 3.05)\end{array}$ & $\begin{array}{l}1.28(0.95 \\
\text { to } 1.74)\end{array}$ & $\begin{array}{l}1.08((0.84 \text { to } \\
1.4)\end{array}$ & $\begin{array}{l}1.00(0.79 \text { to } \\
1.28)\end{array}$ & $\begin{array}{l}1.19(0.96 \text { to } \\
1.47)\end{array}$ & $\begin{array}{l}1.05(0.81 \\
\text { to } 1.38)\end{array}$ & $\begin{array}{l}1.17(1.08 \text { to } \\
1.21)\end{array}$ \\
\hline Higher & $\begin{array}{l}4.82(0.6 \text { to } \\
37.23)\end{array}$ & $\begin{array}{l}2.17(1.42 \\
\text { to } 3.32)\end{array}$ & $\begin{array}{l}2.26(1.42 \text { to } \\
3.60)\end{array}$ & $\begin{array}{l}2.13(0.51 \\
\text { to } 8.93)\end{array}$ & $\begin{array}{l}3.82(2.17 \\
\text { to } 6.73)\end{array}$ & $\begin{array}{l}1.78 \text { (0.58 to } \\
5.47)\end{array}$ & $\begin{array}{l}2.19(0.91 \text { to } \\
5.30)\end{array}$ & $\begin{array}{l}1.30(0.92 \text { to } \\
1.83)\end{array}$ & $\begin{array}{l}2.06(1.20 \\
\text { to } 3.55)\end{array}$ & $\begin{array}{l}1.96(1.65 \text { to } \\
2.33)\end{array}$ \\
\hline \multicolumn{11}{|c|}{ Husband's education } \\
\hline No schooling & 1.00 (ref) & 1.00 (ref) & 1.00 (ref) & 1.00 (ref) & 1.00 (ref) & 1.00 (ref) & 1.00 (ref) & 1.00 (ref) & 1.00 (ref) & 1.00 (ref) \\
\hline Primary & $\begin{array}{l}1.04(0.73 \\
\text { to } 1.48)\end{array}$ & $\begin{array}{l}1.08(0.87 \\
\text { to } 1.36)\end{array}$ & $\begin{array}{l}0.97 \text { (0.83 to } \\
1.15)\end{array}$ & $\begin{array}{l}1.11(0.71 \\
\text { to } 1.75)\end{array}$ & $\begin{array}{l}1.10(0.91 \\
\text { to } 1.33)\end{array}$ & $\begin{array}{l}1.35(1.13 \text { to } \\
1.61)\end{array}$ & $\begin{array}{l}1.18 \text { (0.98 to } \\
1.42)\end{array}$ & $\begin{array}{l}0.86(0.70 \text { to } \\
1.05)\end{array}$ & $\begin{array}{l}1.07(0.81 \\
\text { to } 1.42)\end{array}$ & $\begin{array}{l}1.12(1.05 \text { to } \\
1.20)\end{array}$ \\
\hline Secondary & $\begin{array}{l}0.97(0.72 \\
\text { to } 1.33)\end{array}$ & $\begin{array}{l}1.20(0.93 \\
\text { to } 1.56)\end{array}$ & $\begin{array}{l}1.06 \text { (0.88 to } \\
1.27)\end{array}$ & $\begin{array}{l}1.21(0.77 \\
\text { to } 1.88)\end{array}$ & $\begin{array}{l}0.93(0.69 \\
\text { to } 1.24)\end{array}$ & $\begin{array}{l}1.36(1.09 \text { to } \\
1.71)\end{array}$ & $\begin{array}{l}1.35(1.05 \text { to } \\
1.72)\end{array}$ & $\begin{array}{l}1.01(0.80 \text { to } \\
1.26)\end{array}$ & $\begin{array}{l}1.15(0.86 \\
\text { to } 1.54)\end{array}$ & $\begin{array}{l}1.17(1.09 \text { to } \\
1.27)\end{array}$ \\
\hline Higher & $\begin{array}{l}1.42(0.69 \\
\text { to } 2.93)\end{array}$ & $\begin{array}{l}1.41(1.00 \\
\text { to } 1.97)\end{array}$ & $\begin{array}{l}1.42(1.03 \text { to } \\
1.95)\end{array}$ & $\begin{array}{l}3.57 \text { (0.9 to } \\
14.17)\end{array}$ & $\begin{array}{l}1.42(0.88 \\
\text { to } 2.27)\end{array}$ & $\begin{array}{l}1.32 \text { (0.86 to } \\
2.02)\end{array}$ & $\begin{array}{l}1.38 \text { (0.84 to } \\
2.27)\end{array}$ & $\begin{array}{l}1.22(0.91 \text { to } \\
1.63)\end{array}$ & $\begin{array}{l}1.91(1.23 \\
\text { to } 2.96)\end{array}$ & $\begin{array}{l}1.48(1.31 \text { to } \\
1.69)\end{array}$ \\
\hline \multicolumn{11}{|c|}{ Mother's occupation } \\
\hline Not working $\mathrm{O} / \mathrm{H}$ & 1.00 (ref) & 1.00 (ref) & 1.00 (ref) & 1.00 (ref) & 1.00 (ref) & 1.00 (ref) & 1.00 (ref) & 1.00 (ref) & 1.00 (ref) & 1.00 (ref) \\
\hline $\begin{array}{l}\text { Professional/ } \\
\text { Skilled work }\end{array}$ & $\begin{array}{l}1.99(1.46 \\
\text { to } 2.27)\end{array}$ & $\begin{array}{l}1.19(0.91 \\
\text { to } 1.56)\end{array}$ & $\begin{array}{l}0.97(0.81 \text { to } \\
1.15)\end{array}$ & $\begin{array}{l}1.64(1.11 \\
\text { to } 2.44)\end{array}$ & $\begin{array}{l}1.23(0.91 \\
\text { to } 1.66)\end{array}$ & $\begin{array}{l}1.09 \text { (0.94 to } \\
1.26)\end{array}$ & $\begin{array}{l}1.24 \text { (0.93 to } \\
1.65)\end{array}$ & $\begin{array}{l}1.38(1.18 \text { to } \\
1.62)\end{array}$ & $\begin{array}{l}1.24(1.01 \\
\text { to } 1.50)\end{array}$ & $\begin{array}{l}1.19(1.11 \text { to } \\
1.27)\end{array}$ \\
\hline Agriculture & $\begin{array}{l}1.44(1.06 \\
\text { to } 1.97)\end{array}$ & $\begin{array}{l}0.98(0.83 \\
\text { to } 1.15)\end{array}$ & $\begin{array}{l}1.08 \text { (0.96 to } \\
1.19)\end{array}$ & $\begin{array}{l}2.25(0.75 \\
\text { to } 6.72)\end{array}$ & $\begin{array}{l}1.16(0.87 \\
\text { to } 1.53)\end{array}$ & $\begin{array}{l}0.89(0.76 \text { to } \\
1.04)\end{array}$ & $\begin{array}{l}0.89(0.75 \text { to } \\
1.07)\end{array}$ & $\begin{array}{l}1.26(1.09 \text { to } \\
1.46)\end{array}$ & $\begin{array}{l}1.14(0.96 \\
\text { to } 1.35)\end{array}$ & $\begin{array}{l}1.07(1.01 \text { to } \\
1.13)\end{array}$ \\
\hline Unskilled & $\begin{array}{l}15.54(2.1 \\
\text { to } 114.9)\end{array}$ & $\begin{array}{l}1.06(0.91 \\
\text { to } 1.24)\end{array}$ & $\begin{array}{l}1.07 \text { (0.92 to } \\
1.22)\end{array}$ & $\begin{array}{l}1.58(0.85 \\
\text { to } 2.97)\end{array}$ & $\begin{array}{l}0.79(0.52 \\
\text { to } 1.21)\end{array}$ & $\begin{array}{l}1.09 \text { (0.87 to } \\
1.35)\end{array}$ & $\begin{array}{l}0.95 \text { ( } 0.78 \text { to } \\
1.16)\end{array}$ & $\begin{array}{l}1.62 \text { (1.28 to } \\
2.05)\end{array}$ & $\begin{array}{l}0.96(0.76 \\
\text { to } 1.23)\end{array}$ & $\begin{array}{l}1.13(1.05 \text { to } \\
1.21)\end{array}$ \\
\hline \multicolumn{11}{|l|}{ Wealth quintile } \\
\hline Poorest & 1.00 (ref) & 1.00 (ref) & 1.00 (ref) & 1.00 (ref) & 1.00 (ref) & 1.00 (ref) & 1.00 (ref) & 1.00 (ref) & 1.00 (ref) & 1.00 (ref) \\
\hline Poorer & $\begin{array}{l}0.93(0.70 \\
\text { to } 1.23)\end{array}$ & $\begin{array}{l}1.09(0.91 \\
\text { to } 1.32)\end{array}$ & $\begin{array}{l}1.07 \text { (0.94 to } \\
1.23)\end{array}$ & $\begin{array}{l}0.74(0.48 \\
\text { to } 1.13)\end{array}$ & $\begin{array}{l}1.06(0.87 \\
\text { to } 1.28)\end{array}$ & $\begin{array}{l}1.37(1.19 \text { to } \\
1.58)\end{array}$ & $\begin{array}{l}1.05 \text { (0.87 to } \\
1.26)\end{array}$ & $\begin{array}{l}1.18(1.02 \text { to } \\
1.37)\end{array}$ & $\begin{array}{l}1.09(0.91 \\
\text { to } 1.32)\end{array}$ & $\begin{array}{l}1.12 \text { (1.06 to } \\
1.19)\end{array}$ \\
\hline Middle & $\begin{array}{l}0.93(0.64 \\
\text { to } 1.36)\end{array}$ & $\begin{array}{l}1.18(0.96 \\
\text { to } 1.45)\end{array}$ & $\begin{array}{l}1.09(0.94 \text { to } \\
1.26)\end{array}$ & $\begin{array}{l}0.85(0.53 \\
\text { to } 1.36)\end{array}$ & $\begin{array}{l}1.12(0.91 \\
\text { to } 1.37)\end{array}$ & $\begin{array}{l}1.56(1.32 \text { to } \\
1.86)\end{array}$ & $\begin{array}{l}1.15 \text { (0.95 to } \\
1.40)\end{array}$ & $\begin{array}{l}1.19(1.01 \text { to } \\
1.40)\end{array}$ & $\begin{array}{l}0.96(0.78 \\
\text { to } 1.19)\end{array}$ & $\begin{array}{l}1.18 \text { (1.11 to } \\
1.26)\end{array}$ \\
\hline Richer & $\begin{array}{l}1.88(1.09 \\
\text { to } 3.23)\end{array}$ & $\begin{array}{l}1.21(0.97 \\
\text { to } 1.51)\end{array}$ & $\begin{array}{l}1.07 \text { (0.92 to } \\
1.25)\end{array}$ & $\begin{array}{l}0.79(0.45 \\
\text { to } 1.40)\end{array}$ & $\begin{array}{l}1.04(0.84 \\
\text { to } 1.30)\end{array}$ & $\begin{array}{l}2.26 \text { ( } 1.83 \text { to } \\
2.79)\end{array}$ & $\begin{array}{l}1.62(1.31 \text { to } \\
2.00)\end{array}$ & $\begin{array}{l}1.29 \text { (1.08 to } \\
1.5)\end{array}$ & $\begin{array}{l}0.86(0.64 \\
\text { to } 1.16)\end{array}$ & $\begin{array}{l}1.32 \text { (1.23 to } \\
1.42)\end{array}$ \\
\hline Richest & $\begin{array}{l}4.74(1.9 \text { to } \\
11.95)\end{array}$ & $\begin{array}{l}1.55(1.19 \\
\text { to } 2.04)\end{array}$ & $\begin{array}{l}1.23(1.02 \text { to } \\
1.50)\end{array}$ & $\begin{array}{l}1.31(0.57 \\
\text { to } 3.00)\end{array}$ & $\begin{array}{l}0.77(0.57 \\
\text { to } 1.02)\end{array}$ & $\begin{array}{l}3.62(2.78 \text { to } \\
4.72)\end{array}$ & $\begin{array}{l}1.69(1.27 \text { to } \\
2.24)\end{array}$ & $\begin{array}{l}1.27(1.02 \text { to } \\
1.60)\end{array}$ & $\begin{array}{l}1.17(0.81 \\
\text { to } 1.69)\end{array}$ & $\begin{array}{l}1.41 \text { (1.29 to } \\
1.55)\end{array}$ \\
\hline \multicolumn{11}{|l|}{ Birth order } \\
\hline First & 1.00 (ref) & 1.00 (ref) & 1.00 (ref) & 1.00 (ref) & 1.00 (ref) & 1.00 (ref) & 1.00 (ref) & 1.00 (ref) & 1.00 (ref) & 1.00 (ref) \\
\hline Second & $\begin{array}{l}1.08(0.72 \\
\text { to } 1.63)\end{array}$ & $\begin{array}{l}0.71(0.58 \\
\text { to } 0.87)\end{array}$ & $\begin{array}{l}0.83(0.72 \text { to } \\
0.95)\end{array}$ & $\begin{array}{l}1.22(0.74 \\
\text { to } 1.99)\end{array}$ & $\begin{array}{l}0.72(0.60 \\
\text { to } 0.87)\end{array}$ & $\begin{array}{l}0.88(0.74 \text { to } \\
1.06)\end{array}$ & $\begin{array}{l}0.82(0.68 \text { to } \\
1.00)\end{array}$ & $\begin{array}{l}0.95 \text { (0.80 to } \\
1.13)\end{array}$ & $\begin{array}{l}0.87(0.70 \\
\text { to } 1.08)\end{array}$ & $\begin{array}{l}0.84(0.79 \text { to } \\
0.90)\end{array}$ \\
\hline Third & $\begin{array}{l}0.77(0.52 \\
\text { to } 1.15)\end{array}$ & $\begin{array}{l}0.62(0.51 \\
\text { to } 0.76)\end{array}$ & $\begin{array}{l}0.91(0.79 \text { to } \\
1.05)\end{array}$ & $\begin{array}{l}1.06(0.64 \\
\text { to } 1.76)\end{array}$ & $\begin{array}{l}0.68(0.55 \\
\text { to } 0.83)\end{array}$ & $\begin{array}{l}0.78(0.65 \text { to } \\
0.94)\end{array}$ & $\begin{array}{l}0.72(0.59 \text { to } \\
0.89)\end{array}$ & $\begin{array}{l}0.97(0.81 \text { to } \\
1.16)\end{array}$ & $\begin{array}{l}0.76(0.61 \\
\text { to } 0.96)\end{array}$ & $\begin{array}{l}0.79(0.74 \text { to } \\
0.85)\end{array}$ \\
\hline Fourth & $\begin{array}{l}1.06(0.69 \\
\text { to } 1.64)\end{array}$ & $\begin{array}{l}0.56(0.45 \\
\text { to } 0.70)\end{array}$ & $\begin{array}{l}0.95 \text { (0.82 to } \\
1.11)\end{array}$ & $\begin{array}{l}1.12(0.65 \\
\text { to } 1.94)\end{array}$ & $\begin{array}{l}0.52(0.42 \\
\text { to } 0.66)\end{array}$ & $\begin{array}{l}0.76(0.62 \text { to } \\
0.92)\end{array}$ & $\begin{array}{l}0.71(0.57 \text { to } \\
0.88)\end{array}$ & $\begin{array}{l}0.88(0.73 \text { to } \\
1.07)\end{array}$ & $\begin{array}{l}0.91(0.71 \\
\text { to } 1.17)\end{array}$ & $\begin{array}{l}0.77(0.72 \text { to } \\
0.83)\end{array}$ \\
\hline Fifth \& above & $\begin{array}{l}0.75(0.52 \\
\text { to } 1.08)\end{array}$ & $\begin{array}{l}0.50(0.41 \\
\text { to } 0.61)\end{array}$ & $\begin{array}{l}0.98(0.85 \text { to } \\
1.12)\end{array}$ & $\begin{array}{l}0.79(0.49 \\
\text { to } 1.26)\end{array}$ & $\begin{array}{l}0.50(0.41 \\
\text { to } 0.61)\end{array}$ & $\begin{array}{l}0.68(0.58 \text { to } \\
0.80)\end{array}$ & $\begin{array}{l}0.61(0.51 \text { to } \\
0.73)\end{array}$ & $\begin{array}{l}0.77(0.65 \text { to } \\
0.90)\end{array}$ & $\begin{array}{l}0.73(0.59 \\
\text { to } 0.90)\end{array}$ & $\begin{array}{l}0.68(0.64 \text { to } \\
0.73)\end{array}$ \\
\hline \multicolumn{11}{|c|}{ Frequency of listening to radio/reading newspaper/magazines } \\
\hline Not at all & 1.00 (ref) & $1.00($ ref) & 1.00 (ref) & $1.00($ ref) & $1.00($ ref) & 1.00 (ref) & 1.00 (ref) & 1.00 (ref) & 1.00 (ref) & 1.00 (ref) \\
\hline $\begin{array}{l}\text { Less than once a } \\
\text { week }\end{array}$ & $\begin{array}{l}1.47(1.08 \\
\text { to } 2.00)\end{array}$ & $\begin{array}{l}1.35(1.08 \\
\text { to } 1.68)\end{array}$ & $\begin{array}{l}1.05(0.94 \text { to } \\
1.20)\end{array}$ & $\begin{array}{l}1.94(1.22 \\
\text { to } 3.07)\end{array}$ & $\begin{array}{l}0.95(0.78 \\
\text { to } 1.17)\end{array}$ & $\begin{array}{l}1.06(0.87 \text { to } \\
1.29)\end{array}$ & $\begin{array}{l}1.11(0.93 \text { to } \\
1.33)\end{array}$ & $\begin{array}{l}1.13(0.96 \text { to } \\
1.34)\end{array}$ & $\begin{array}{l}1.01(0.80 \\
\text { to } 1.28)\end{array}$ & $\begin{array}{l}1.08(1.01 \text { to } \\
1.15)\end{array}$ \\
\hline $\begin{array}{l}\text { At least once a } \\
\text { week }\end{array}$ & $\begin{array}{l}2.62(1.96 \\
\text { to } 3.50)\end{array}$ & $\begin{array}{l}1.21(1.02 \\
\text { to } 1.44)\end{array}$ & $\begin{array}{l}1.09 \text { (0.98 to } \\
1.22)\end{array}$ & $\begin{array}{l}2.31(1.51 \\
\text { to } 3.53)\end{array}$ & $\begin{array}{l}1.07(0.88 \\
\text { to } 1.30)\end{array}$ & $\begin{array}{l}1.14(0.96 \text { to } \\
1.35)\end{array}$ & $\begin{array}{l}1.34(1.12 \text { to } \\
1.60)\end{array}$ & $\begin{array}{l}1.24 \text { (1.09 to } \\
1.41)\end{array}$ & $\begin{array}{l}1.05(0.85 \\
\text { to } 1.30)\end{array}$ & $\begin{array}{l}1.22(1.15 \text { to } \\
1.29)\end{array}$ \\
\hline
\end{tabular}

All are adjusted for sociodemographic factors and media exposure.

Bold font indicates a significant difference from reference at $p<0.05$

${ }^{*}$ Adjusted for sociodemographic factors, media exposure and country.

$4^{+} \mathrm{ANC}$, four or more antenal care; $\mathrm{O} / \mathrm{H}$, outside home. 
countries. The odds of $4^{+} \mathrm{ANC}$ visits among women who had access to media at least once a week were more than twofold higher in Ghana (AOR 2.62, 95\% CI: 1.96 to 3.50) and Namibia (AOR 2.31, 95\% CI: 1.51 to 3.53). This association was not significant in Rwanda, Senegal, Malawi and Zambia. 8111823

In summary, despite the importance of attending the WHO recommended level of at least four ANC visits for a normal pregnancy, ${ }^{1}$ many women in SSA have limited access. The result of this study indicates that disparities on $4^{+} \mathrm{ANC}$ visits were related to women's economic situation as well as physical barriers. ${ }^{12} 25$ Therefore, interventions on addressing the inequalities on ANC services used among women from rural areas and with limited resources are crucial. The relatively high utilisation of ANC in Ghana could be due to community-based health insurance. ${ }^{82127}$ Furthermore, governments committed to community insurance are crucial to avoid the challenges faced in countries like Rwanda, which was functional in $1999-2012^{34}$, but not in 2014/2015.

Women and husbands with higher education, exposed to outside home occupation and who had exposure to media had positive results on the uptake of $4^{+}$ANC visits. Educated women and their husbands as well as those in employment presumably knew the importance of adequate $\mathrm{ANC}$ attendance.

\section{Conclusion and recommendation}

Four or more ANC service utilisation is low among women of the SSA countries. Despite its importance, countries had varied practices of $4^{+} \mathrm{ANC}$ visits.

Therefore, regional and country-specific maternal health programme interventions are required to address the barriers of adequate ANC visits. Moreover, health programmes should target women from rural areas, without schooling, no outside home occupation, from low household economic status, non-first-time pregnancy and had no access to media.

Twitter Amanuel Kidane Andegiorgish @Amanuel03925331 and Mohamed Elhoumed @MElhoumed

Acknowledgements The authors are grateful to the MEASURE DHS, ICF international, Rockville, Maryland, USA for providing the data for analysis.

Contributors AKA — conceptualisation, study methodology, literature review, data acquisition, formal analysis, interpretation of data and writing (original draft). AKA, LZ, ZZ, ME and QQ —writing (review and editing). LZ - visualisation and supervision. AKA and LZ-administration. All authors read and approved the final manuscript. AKA is responsible for the overall content as guarantor.

Funding The authors have not declared a specific grant for this research from any funding agency in the public, commercial or not-for-profit sectors.

Competing interests None declared.

Patient and public involvement Patients and/or the public were not involved in the design, or conduct, or reporting, or dissemination plans of this research.

\section{Patient consent for publication Not required.}

Ethics approval This study was exempt from review by the ethics committee as publicly available data sets were used and no identifying participant information was obtained. The authorisation for using the data in the current analysis was granted from the DHS programme: DHS, ICF international, Rockville, Maryland, USA office upon presenting the research protocol and research plan aims.
Provenance and peer review Not commissioned; externally peer reviewed.

Data availability statement Data are available upon reasonable request. Data sets used in the analysis are publicly available and can be accessed online through an application to MEASURE DHS. Analysis syntax and outputs generated for the study can be made available upon request to the corresponding author.

Open access This is an open access article distributed in accordance with the Creative Commons Attribution Non Commercial (CC BY-NC 4.0) license, which permits others to distribute, remix, adapt, build upon this work non-commercially, and license their derivative works on different terms, provided the original work is properly cited, appropriate credit is given, any changes made indicated, and the use is non-commercial. See: http://creativecommons.org/licenses/by-nc/4.0/.

\section{ORCID iDs}

Amanuel Kidane Andegiorgish http://orcid.org/0000-0002-3045-3153

Mohamed Elhoumed http://orcid.org/0000-0001-7876-7904

Lingxia Zeng http://orcid.org/0000-0002-4649-9818

\section{REFERENCES}

1 World Health Organization. WHO recommendations on antenatal care for a positive pregnancy experience. Geneva: World Health Organization, 2016.

2 World Health Organization. Trends in maternal mortality 2000 to 2017: estimates by WHO, UNICEF, UNFPA, world bank group and the United nations population division. Geneva: World Health Organization, 2019.

3 United Nations Inter-agency Group for Child Mortality Estimation (UNIGME) UNCsF. Levels \& trends in child mortality: report 2019, estimates developed by the United Nations Inter-agency Group for Child Mortality Estimation. New York, 2019.

4 Hug L, Alexander M, You D, et al. National, regional, and global levels and trends in neonatal mortality between 1990 and 2017, with scenario-based projections to 2030: a systematic analysis. Lancet Glob Health 2019;7:e710-20.

5 Alliance for Maternal and Newborn Health Improvement (AMANHI) Mortality Study Group. Population-based rates, timing, and causes of maternal deaths, stillbirths, and neonatal deaths in South Asia and sub-Saharan Africa: a multi-country prospective cohort study. Lancet Glob Health 2018;6:e1297-308.

$6 \mathrm{WHO}$. Antenatal care in developing countries promises, achievements and missed opportunities, an analysis of trends, levels and differentials, 1990-2001 2003;36.

7 Moller A-B, Petzold M, Chou D, et al. Early antenatal care visit: a systematic analysis of regional and global levels and trends of coverage from 1990 to 2013. Lancet Glob Health 2017;5:e977-83.

8 Tekelab T, Chojenta C, Smith R, et al. Factors affecting utilization of antenatal care in Ethiopia: a systematic review and meta-analysis. PLoS One 2019;14:e0214848.

9 Tekelab T, Chojenta C, Smith R, et al. The impact of antenatal care on neonatal mortality in sub-Saharan Africa: a systematic review and meta-analysis. PLoS One 2019;14:e0222566.

10 Woldegiorgis MA, Hiller J, Mekonnen W, et al. Determinants of antenatal care and skilled birth attendance in sub-Saharan Africa: a multilevel analysis. Health Serv Res 2019;54:1110-8.

11 Tripathi V, Singh R. Regional differences in usage of antenatal care and safe delivery services in Indonesia: findings from a nationally representative survey. BMJ Open 2017;7:e013408.

12 Rosário EVN, Gomes MC, Brito M, et al. Determinants of maternal health care and birth outcome in the Dande health and demographic surveillance system area, Angola. PLoS One 2019;14:e0221280.

13 Aziz Ali S, Ahmed Dero A, Aziz Ali S, et al. Factors affecting the utilization of antenatal care among pregnant women: a literature review. J Preg Neonatal Med 2018;02:41-5.

14 Ribeiro ERO, Guimarães AMDN, Bettiol H, et al. Risk factors for inadequate prenatal care use in the metropolitan area of Aracaju northeast Brazil. BMC Pregnancy Childbirth 2009;9:31.

15 Nimi T, Fraga S, Costa D, et al. Prenatal care and pregnancy outcomes: a cross-sectional study in Luanda, Angola. Int J Gynaecol Obstet 2016;135:S72-8.

16 Guliani H, Sepehri A, Serieux J. Determinants of prenatal care use: evidence from 32 low-income countries across Asia, sub-Saharan Africa and Latin America. Health Policy Plan 2014;29:589-602.

17 Titaley CR, Dibley MJ, Roberts CL. Factors associated with underutilization of antenatal care services in Indonesia: results of Indonesia demographic and health survey 2002/2003 and 2007. BMC Public Health 2010;10:485. 
18 Simkhada B, Teijlingen ERvan, Porter M, et al. Factors affecting the utilization of antenatal care in developing countries: systematic review of the literature. J Adv Nurs 2008;61:244-60.

19 Aliyu AA, Dahiru T. Predictors of delayed antenatal care (ANC) visits in Nigeria: secondary analysis of 2013 Nigeria demographic and health survey (NDHS). Pan Afr Med J 2017;26:124.

20 Tang X, Ding L, Feng Y. Antenatal care use and its determinants among migrant women during the first delivery: a nation-wide crosssectional study in China. BMC Preg Child 2019;19:355.

21 Sakeah E, Okawa S, Rexford Oduro A, et al. Determinants of attending antenatal care at least four times in rural Ghana: analysis of a cross-sectional survey. Glob Health Action 2017;10:1291879.

22 Mekonnen T, Dune T, Perz J, et al. Trends and determinants of antenatal care service use in Ethiopia between 2000 and 2016. Int J Environ Res Public Health 2019;16 doi:10.3390/ijerph16050748

23 Ogbo FA, Dhami MV, Ude EM, et al. Enablers and barriers to the utilization of antenatal care services in India. Int J Environ Res Public Health 2019;16:3152.

24 El-Khatib Z, Kolawole Odusina E, Ghose B, et al. Patterns and predictors of insufficient antenatal care utilization in Nigeria over a decade: a pooled data analysis using demographic and health surveys. Int J Environ Res Public Health 2020;17 doi:10.3390/ ijerph17218261

25 Asundep NN, Carson AP, Turpin CA, et al. Determinants of access to antenatal care and birth outcomes in Kumasi, Ghana. J Epidemio Glob Health 2013;3:279-88.

26 Woldegiorgis MA, Hiller JE, Mekonnen W, et al. Disparities in maternal health services in sub-Saharan Africa. Int J Public Health 2018;63:525-35.
27 Alam N, Hajizadeh M, Dumont A, et al. Inequalities in maternal health care utilization in sub-Saharan African countries: a multiyear and multi-country analysis. PLoS One 2015;10:e0120922.

28 United Nations. Transforming our world: the 2030 agenda for sustainable development (2019), 2015. Available: https://sustainable development nt.un.org/SDG [Accessed 28 Nov 2020].

29 Owolabi OO, Wong KLM, Dennis ML, et al. Comparing the use and content of antenatal care in adolescent and older first-time mothers in 13 countries of West Africa: a cross-sectional analysis of demographic and health surveys. Lancet Child Adolesc Health 2017;1:203-12.

30 Corsi DJ, Neuman M, Finlay JE, et al. Demographic and health surveys: a profile. Int J Epidemiol 2012;41:1602-13

31 Filmer D, Pritchett LH. Estimating wealth effects without expenditure data-or tears: an application to educational enrollments in states of India. Demography 2001;38:115-32.

32 Ghose B, Feng D, Tang S, et al. Women's decision-making autonomy and utilisation of maternal healthcare services: results from the Bangladesh demographic and health survey. BMJ Open 2017;7:e017142.

33 Shahabuddin A, De Brouwere V, Adhikari R, et al. Determinants of institutional delivery among young married women in Nepal: evidence from the Nepal demographic and health survey, 2011. BMJ Open 2017;7:e012446.

34 Nyandekwe M, Nzayirambaho M, Kakoma JB. Universal health insurance in Rwanda: major challenges and solutions for financial sustainability case study of Rwanda community-based health insurance part I. Pan Afr Med J 2020;37:55. 